Journal of Agriculture, Food and Environment (JAFE)

Journal Homepage: $\underline{\text { http://journal.safebd.org/index.php/jafe }}$

http://doi.org/10.47440/JAFE.2021.2115

Original Article

\title{
Shading effect of multipurpose trees on growth and yield of Boro rice cv. BRRI dhan29
}

\author{
M. B. Hossain ${ }^{1}$, M. K. Hasan ${ }^{2}$, S. A. K. Hemel ${ }^{2}$, N. A. Roshni ${ }^{2}$ and S. R. Sadik ${ }^{3}$ \\ ${ }^{1}$ Upazila Agriculture Officer, Department of Agricultural Extension (DAE), Nikli, Kishoreganj, Bangladesh \\ ${ }^{2}$ Department of Agroforestry, Faculty of Agriculture, Bangladesh Agricultural University, Mymensingh 2202, Bangladesh \\ ${ }^{3}$ Department of Forestry and Environmental Science, Shahjalal University of Science and Technology, Sylhet
}

\section{A B S T R A C T}

\section{Article History}

Received: 9 March 2021

Revised: 27 March 2021

Accepted: 30 March 2021

Published online: 31 March 2021

\section{*Corresponding Author}

M. K. Hasan, E-mail:

mkhasanaf@bau.edu.bd

\section{Keywords}

Tree shade, boro rice, grain yield, agroforestry system
A field experiment was conducted during Rabi season (December-May) to compare the vegetative growth and yield of Boro rice cv. BRRI dhan29 under tree shade and ambient (shade free) condition in Boira village at Sadar upazila of Mymensingh district. In this study, twelve years old Mango (Mangifera indica), eight years old Mahogany (Swietenia macrophylla) and ten years old Sissoo (Dalbergia sissoo) trees were selected as treatment and each of the tree had six replications. The experiment was laid out in a two factorial Randomized Complete Block Design (RCBD). To achieve the objective, the parameters reflect on growth, yield and yield contributing characters were recorded at different stages of rice plants under both tree shade and ambient condition. The result showed that different treatments significantly influenced on the growth and yield contributing components viz. plant height, effective tillers hill ${ }^{-1}$, leaf number hill ${ }^{-1}$, leaf area hill ${ }^{-1}$, panicle length, filled spikelet's panicle ${ }^{-1}$ and grain yield. The maximum (5.20 tha $^{-1}, 7.65$ tha $^{-1}$ and 13.20 tha $^{-1}$ ) grain yield, straw yield and biological yield of rice was produced in the Mango ambient condition and the minimum (1.68 tha $\left.^{-1}\right)$ grain yield in the Mango tree shade and straw yield and biological yield (3.64 tha $\mathrm{t}^{-1}$ and $5.93 \mathrm{tha}^{-1}$ ) was produced in the Mahogany tree shade area. The highest $(43.87 \%)$ harvest index of rice was recorded in Mahogany tree ambient area and the lowest $(24.94 \%)$ in Mango tree shade area. From the above results, it was found that maximum (68\%) reduction of rice grain yield was recorded under Mango tree shade, moderate $(28 \%)$ under the shade of Mahogany tree where as no rice grain yield reduction was occurred in Sissoo tree shade and ambient condition. Therefore, it can be concluded that in consideration of shade casted by different trees, Sissoo-Boro rice and Mahogany-Boro rice based agroforestry systems is suitable in second case although there was some yield loss $(28 \%)$ compare to Mango-Boro rice agroforestry system.

(C) Society of Agriculture, Food and Environment (SAFE)

\section{Introduction}

Rice is grown throughout Bangladesh except in the southeastern hilly areas. The agro-climatic conditions of the country are suitable for growing rice year-round. Since, independence, there has been a three-fold increase in rice production in Bangladesh, which jumped from nearly $11 \mathrm{MT}$ in 1971-72 to about 34.86 MT in 2014-15 (AIS, 2016). Boro rice is the dry-season irrigated crop planted from December to February and harvested between April and June. Earlier, Boro rice is grown in the low-lying areas with residual water from the wet season and irrigated manually using surface water in times of water shortage (Fujita, 2010).

Agroforestry is an age-old practice in the traditional farming systems in the tropics including Bangladesh (Karim and Savill, 1991). Farmers of Bangladesh like many other Asian countries have been growing cereals, root crops, fiber, vegetables, and fruit in association with the trees and another woody perennial (Gujral, 1990). Cropland agroforestry is a production technique or agroforestry farming practices that mix agricultural crops and forestry on a bit of land to maximize the use of natural resources (Torquesiau, 1994). In 
Nepal for instance, there was a four-fold increase in the density of trees in farms in crop-growing areas (Gilmour, 1995). Farmers in our country practice monoculture of Boro rice. But practicing of suitable tree rice association can increase total production than the mono crop system.

The growth and yield of Boro rice is greatly affected by sunlight. Several studies have shown that in shading experiments at different growth periods of crops, shading after grain filling at the seed bearing stage has the greatest impact on grain filling condition, quality formation, and yield (Deng et al., 2009; Ren et al., 2003). The rice plants in shade free area increases number of leaves encouraged more photosynthesis resulting in higher production (Singh, 1988; Sutater, 1987). Tree shade influences to increase plant height, decreases tiller and panicle number hill ${ }^{-1}$ and grains panicle $^{-1}$ and decreases grain yield. It stimulates cellular expansion and rapid cell division resulting increase leaf length and plant height except shade loving or tolerant plants (Schoch, 1972). Shading treatment showed that the tallest plants and on the other hand, smallest plants are observed under shade free area (Miah et al., 1999). Consideration of shading effects of different trees on growth and yield of rice, Jhau-Aman rice based agroforestry system is found more suitable than Akashmoni and Eucalyptus tree rice based agroforestry system reported by Sharif et al., 2010. Trees compete with rice for water, nutrient, weed infestation and allelopathic effects which exert negative influence on rice growth and yield. So, it is very much essential to evaluate the shading effect of different multipurpose trees on growth and yield of Boro rice cv. BRRI dhan29. Considering the aforementioned facts, the study was carried out to evaluate the vegetative growth and yield of Boro rice cv. BRRI dhan29 under Mango, Mahogany and Sissoo tree shade and ambient (shade free) condition and also to find out the suitability of growing above trees in the boundary of Boro rice field.

\section{Methodology}

The experiment was conducted at Boira village under Sadar upazila of Mymensingh district (Figure 1) during Rabi season (December-May). The experimental site is located at $24^{\circ} 4^{\prime}$ North latitude and $90^{\circ} 24^{\prime}$ East longitude. The land of the experimental field was medium high in elevation belongs to the Agro-ecological zone-9 of the old Brahmaputra Flood Plain under Sonatola soil series. The soil texture is silty loam is characterized by non-calcareous dark grey flood plain soil having $\mathrm{pH}$ value from 6.5 to 6.8 (FAO, 1988). The climate of the area is subtropical characterized by a distinct wet season from May to October and a dry season from November to April. The experiment was carried out in a two factorial Randomized Complete Block Design (RCBD) with six replications. The following treatments were used in this experiment:

Factor A: Tree species- Mango (Mangifera indica), Mahogany (Swietenia macrophylla) and Sissoo (Dalbergia sissoo)

Factor B: Sunshine condition- Shade and ambient (shade free)

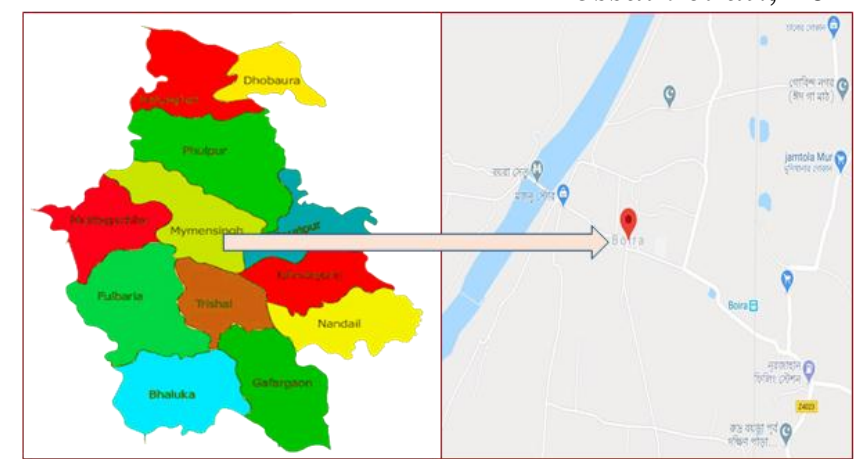

Fig. 1. Map showing the study area (Boira village under Sadar upazila of Mymensingh)

The experimental field was ploughed in wet condition with power tiller followed by laddering. The land was puddle thoroughly by ploughing and cross ploughing followed by laddering in order to level the soil. Weed and other stubbles were removed from the field. The recommended doses of all fertilizers except urea were applied in the experimental plots during final land preparation. Urea fertilizer was applied in three equal splits at 10,30 and 45 days after transplanting, respectively (FRG, 2012). Forty (40) days old seedlings of BRRI dhan29 were transplanted on with spacing $20 \mathrm{~cm} \times 15$ $\mathrm{cm}$. Two or three healthy seedlings per hill were transplanted in the experimental plots. After transplanting, necessary cultural operations were done as required.

The sunshine intensity of shade under different tree (i.e. mango, mahogany and sissoo) and non-shade ambient area were measured on 19, 26 and 28 April with the help of light photo meter (Model LI-250, LICOR, USA). The sunshine intensity in both shade and ambient area were recorded in the morning (9:40 am), early noon (11:50 am), noon (12:25 pm), late noon $(1: 30 \mathrm{pm})$, early afternoon $(2: 30 \mathrm{pm})$ and afternoon $(3: 15 \mathrm{pm})$.

The rice harvested at its full maturity. The rice in shade area of sissoo, mango and mahogany trees were harvested at 111, 125 and 125 days after transplanting (DAT) and shade free area of these trees at 111 DAT. Two types of sampling were collected; one for growth parameters and the other related to yield and yield parameters at harvest time. At each sampling, six hills were uprooted from each of shading condition and shade free area (i.e. ambient condition) under mango, mahogany and sissoo trees. The growth characteristics of rice plant such as plant height $(\mathrm{cm})$, number of tillers hill ${ }^{-1}$, number of leaves hill ${ }^{-1}$ were counted at 79, 86, 93 and 100 DAT. Then the plant parts such as root, leaf, stem and panicles (after panicle initiation) were separated and weighed. Leaf area was measured by using an electronic leaf area meter. The leaf area of the rest hills was calculated from the oven dries of measured leaf weight. The data on total tillers hill ${ }^{-1}$, number of effective tillers hill ${ }^{-1}$, number of panicle hill ${ }^{-1}$, panicle length $(\mathrm{cm})$, filled grain panicle ${ }^{-1}$, unfilled grain panicle ${ }^{-1}$, panicle weight $(\mathrm{g})$, straw weight $(\mathrm{g})$, 1000 grains weight $(\mathrm{g})$, grain yield, straw yield $\left(\right.$ tha $\left.^{-1}\right)$, biological yield $\left(\mathrm{tha}^{-1}\right)$ and harvest index $(\%)$ were recorded at final harvest. The data were statistically analyzed to test the level of significance and the means were ranked by Duncan's Multiple Range Test (DMRT). 


\section{Results and Discussion}

Morphological characteristics of Boro rice cv. BRRI dhan29 at vegetative stage

\section{Plant height (cm)}

The significant response was observed in case of pant height due to shading effect of different tree species (Table 1). The plant height of rice varied significantly due to different trees and sunshine condition. In all cases rice plant height was increased from 79 DAT to 93 DAT and then platitude (Table 1). It was recorded that out of three tree-rice associations, the highest $(98.83 \mathrm{~cm})$ and the lowest $(73.92 \mathrm{~cm})$ plant height of rice were found in the mango tree shade area and sissoo tree in ambient area (Table 1). In mahogany trees rice plant grown in the shade area possessed lesser height than rice grown in ambient condition (Table 1). The plant height of rice under Sissoo tree shade and ambient condition did not varied significantly. They are more or less statistically similar (Table 1). Similar results were found by Alridiwirsah et al., (2018) in their study where they reported that at 14 weeks after planting of rice plant out of the three shading condition, the highest $(115.88 \mathrm{~cm})$ and the lowest $(110.85$ $\mathrm{cm})$ plant height of rice were found at $20 \%$ shading condition and no shading condition which were very much supportive to the present findings.

Table 1. Shading effects of different trees on plant height, number of tillers hill' ${ }^{-1}$, leaf numbers hill ${ }^{-1}$ and leaf area hill ${ }^{-1}$ of Boro rice cv. BRRI dhan29 at vegetative stage

\begin{tabular}{|c|c|c|c|c|c|c|c|c|c|c|c|c|c|c|c|c|c|}
\hline \multirow[t]{3}{*}{ Trees } & \multirow{3}{*}{$\begin{array}{l}\text { Sunshine } \\
\text { condition }\end{array}$} & \multicolumn{4}{|c|}{ Plant height (cm) } & \multicolumn{4}{|c|}{ Number of tillers hill $^{-1}$} & \multicolumn{4}{|c|}{ Leaf number hill $^{-1}$} & \multicolumn{4}{|c|}{ Leaf area $\left(\mathrm{cm}^{2}\right)$ hill $^{-1}$} \\
\hline & & 79 & 86 & 93 & 100 & 79 & 86 & 93 & 100 & 79 & 86 & 93 & 100 & 79 & 86 & 93 & 100 \\
\hline & & DAT & DAT & DAT & DAT & DAT & DAT & DAT & DAT & DAT & DAT & DAT & DAT & DAT & DAT & DAT & DAT \\
\hline \multirow[t]{2}{*}{ Mango } & $\mathrm{S}$ & $91.17 \mathrm{a}$ & $93.25 \mathrm{a}$ & $98.83 \mathrm{a}$ & $97.83 \mathrm{a}$ & 7.83 & 8.67 & 8.33 & 8.17 & $31.50 \mathrm{a}$ & $36.67 \mathrm{ab}$ & $36.83 \mathrm{ab}$ & $36.67 \mathrm{ab}$ & $2148.96 a$ & $2520.83 a$ & $2532.29 a$ & $2554.17 \mathrm{a}$ \\
\hline & An & $83.12 b$ & $89.00 \mathrm{ab}$ & $90.17 \mathrm{~b}$ & $90.25 b c$ & 7.83 & 8.50 & 8.17 & 8.00 & $30.17 \mathrm{a}$ & $39.33 \mathrm{a}$ & $39.67 \mathrm{a}$ & $38.83 \mathrm{a}$ & & $7 b$ & $1556.92 \mathrm{~b}$ & $1524.21 \mathrm{~b}$ \\
\hline \multirow{2}{*}{ Mahogany } & Shade & $75.87 \mathrm{c}$ & $83.72 b c$ & $89.27 b c$ & $89.53 b c$ & 6.50 & 6.67 & 6.50 & 6.50 & $30.17 \mathrm{a}$ & $37.33 \mathrm{ab}$ & $36.00 \mathrm{ab}$ & $37.17 \mathrm{ab}$ & 1. & 26 & 14 & $1419.77 b$ \\
\hline & Ambient & $83.50 \mathrm{~b}$ & $88.47 \mathrm{ab}$ & $94.63 \mathrm{ab}$ & $94.95 \mathrm{ab}$ & 5.83 & 6.17 & 6.00 & 5.83 & $30.67 \mathrm{a}$ & $7 b$ & $33.00 \mathrm{ab}$ & $30.00 \mathrm{c}$ & 125 & 139 & $7 b c$ & $1297.50 \mathrm{~b}$ \\
\hline \multirow[t]{2}{*}{ Sissoo } & Shade & $77.08 \mathrm{bc}$ & $82.92 b c$ & $83.50 \mathrm{~d}$ & $84.17 \mathrm{c}$ & 7.50 & 8.33 & 7.50 & 7.33 & $26.17 \mathrm{ab}$ & $32.00 \mathrm{~b}$ & $32.17 \mathrm{~b}$ & $32.33 b c$ & $1004.80 \mathrm{c}$ & $1228.80 b$ & $1235.20 \mathrm{c}$ & $1241.60 \mathrm{~b}$ \\
\hline & Ambient & $73.92 \mathrm{c}$ & $78.92 \mathrm{c}$ & $84.25 \mathrm{~cd}$ & $84.58 \mathrm{c}$ & 7.17 & 7.50 & 7.50 & 7.50 & $22.50 \mathrm{~b}$ & $32.00 \mathrm{~b}$ & $35.33 \mathrm{ab}$ & $34.67 \mathrm{abc}$ & $957.04 \mathrm{c}$ & $1409.58 \mathrm{~b}$ & $1501.67 \mathrm{bc}$ & $1473.33 b$ \\
\hline \multicolumn{2}{|l|}{$\mathrm{CV}(\%)$} & 6.53 & 5.66 & 4.92 & 5.83 & 17.59 & 26.75 & 15.43 & 18.39 & 5.45 & 5.65 & 6.03 & 5.05 & 10.12 & 5.98 & 8.59 & 8.95 \\
\hline \multicolumn{2}{|c|}{ Level of significance } & $*$ & $*$ & $*$ & * & NS & NS & NS & NS & $*$ & $*$ & $*$ & $*$ & $* *$ & $* *$ & $* *$ & ** \\
\hline
\end{tabular}

Note: In a column, figures having the similar letter(s) or without letter(s) do not differ significantly as per DMRT; *= Significant at $5 \%$ level of probability; $* *=$ Significant at $1 \%$ level of probability; NS= Non-significant.

\section{Number of tillers hill ${ }^{-1}$}

The number of tillers hill ${ }^{-1}$ of rice was found non-significant at 79 to 100 DAT due to shade and ambient condition (Table 1). The number of tillers hill ${ }^{-1}$ was increased up to 93 DAT and trees had no significant effect on number of tillers hill ${ }^{-1}$. However, number of tillers hill $^{-1}$ of rice produced in the shade area was comparatively higher than the number of tillers hill ${ }^{-1}$ produced in the shade free area (i.e. ambient condition). It represents that shade has tendency to increase the number of tillers hill ${ }^{-1}$ (Table 1). Islam (2007) reported that number of tillers hill ${ }^{-1}$ was gradually affected with the intensities of shade and except control the highest number of tillers hill $^{-1}$ (14.33) was found in Eucalyptus-Aman rice based agroforestry with shade condition at late afternoon in his study which was supportive with this result. Ginting et al., (2015) found that the highest number of tillers (28.26) and (27.03) were found in variety of Situ Bagendit $\left(\mathrm{V}_{3}\right)$ and Tuwoti $\left(\mathrm{V}_{4}\right)$ in the shade of $0 \%$ and the lowest for the local variety of $\mathrm{Si}$ Kembiri $\left(\mathrm{V}_{1}\right)$ (11.89) in the shade of $40 \%$.

\section{Leaf number hill ${ }^{-1}$}

Generally, leaf number is a good indication of growth and development of crop. The greater number of leaves and the greater photosynthetic area indicates the higher yield of crop. The leaf number hill $^{-1}$ was significantly influenced due to shading effect of different trees (Table 1). Leaf number hill ${ }^{-1}$ increased up to 93 DAT and then after decreased. It was reported that among those tree-rice associations, the highest leaf number hill $^{-1}$ (39.7) was found under Mango tree at ambient condition at 93 DAT (Table 1). The lowest number of leaves hill $^{-1}$ (22.5) was found under sissoo-rice agroforestry system at ambient condition (Table 1). The similar type of findings observed by Hossain (2008) in his experiment where he found that the highest (64.48) and the lowest (60.13) number of leaves hill ${ }^{-1}$ produced by Jhau-
Aman rice agroforestry system at unpruned to slightly pruned condition.

\section{Leaf area $\left(\mathrm{cm}^{2}\right)$ hill $^{-1}$}

Leaf area $\left(\mathrm{cm}^{2}\right)$ hill ${ }^{-1}$ was significantly influenced due to shading effect of different trees. It was found that out of three tree-rice associations, the highest leaf area hill $^{-1}$ $\left(2554.17 \mathrm{~cm}^{2}\right)$ and the lowest leaf area hill-1 $\left(1228.80 \mathrm{~cm}^{2}\right)$ were recorded under mango tree shade and sissoo tree shade areas (Table 1). Statistically no significant difference was found on leaf area of rice in case of shade and ambient area of mahogany and sissoo trees (Table 1). Srikrishnah et al., (2012) reported that the Dracaena plants grown at 50\% and $70 \%$ shade levels produced the highest leaf area $(911.67$ $\left.\mathrm{cm}^{2}\right)$ and $\left(924.00 \mathrm{~cm}^{2}\right)$ than the plants of $80 \%$ shade where leaf area $\left(287.67 \mathrm{~cm}^{2}\right)$.

\section{Yield and yield contributing characters of Boro rice cv. BRRI dhan29 at harvesting stage} Total tillers hill ${ }^{-1}$

The results revealed that total tillers hill $^{-1}$ was significantly affected by the shade and ambient sunshine condition (Table 2 ). The highest total tillers hill ${ }^{-1}$ of rice (7.67) produced in ambient condition of mango tree which statistically similar in shade condition of sissoo trees. The lowest total tillers hill ${ }^{-1}$ of boro rice (5.83) was found in shade and ambient condition of mahogany trees which were numerically and statistically similar (Table 2). The total tillers hill ${ }^{-1}$ of Aman rice cv. BRRI dhan30 was not significantly affected by the shading times reported by Sharif et al. (2010) in their study where the highest number of total tillers hill ${ }^{-1}(12.67)$ was found in the shade free area of jhau tree which was supportive to the study findings. 
Table 2. Shading effects of different trees on yield and yield contributing characters of Boro rice cv. BRRI dhan29 at harvesting stage

\begin{tabular}{|c|c|c|c|c|c|c|c|c|c|c|c|c|}
\hline Trees & $\begin{array}{l}\text { Sunshine } \\
\text { condition }\end{array}$ & $\begin{array}{c}\text { Total } \\
\text { tillers } \\
\text { hill }^{-1}\end{array}$ & $\begin{array}{c}\text { Effective } \\
\text { tillers } \\
\text { hill }^{-1}\end{array}$ & $\begin{array}{c}\text { Non- } \\
\text { effective } \\
\text { tillers } \\
\text { hill }^{-1}\end{array}$ & $\begin{array}{c}\text { Panicle } \\
\text { length } \\
\text { (cm) }\end{array}$ & $\begin{array}{c}\text { Filled } \\
\text { grains } \\
\text { panicle }^{-1}\end{array}$ & $\begin{array}{c}\text { Unfilled } \\
\text { grain } \\
\text { panicle }^{-1}\end{array}$ & $\begin{array}{c}\text { 1000- } \\
\text { grain } \\
\text { weight } \\
(\mathrm{g}) \\
\end{array}$ & $\begin{array}{c}\text { Grain } \\
\text { yield } \\
\left(\text { tha }^{-1}\right)\end{array}$ & $\begin{array}{c}\text { Straw } \\
\text { yield } \\
\left(\text { tha }^{-1}\right)\end{array}$ & $\begin{array}{c}\text { Biologica } \\
\text { l yield } \\
\left(\text { tha }^{-1}\right)\end{array}$ & $\begin{array}{c}\text { Harvest } \\
\text { index } \\
(\%)\end{array}$ \\
\hline \multirow[t]{2}{*}{ Mango } & & $6.50 \mathrm{~b}$ & & $0.17 \mathrm{a}$ & & & & $17.73 \mathrm{de}$ & $1.68 \mathrm{e}$ & $4.54 \mathrm{bc}$ & $6.21 \mathrm{c}$ & 24. \\
\hline & & $7.67 \mathrm{a}$ & $67 \mathrm{a}$ & $0.00 \mathrm{~b}$ & 20.7 & $5 \mathrm{~b}$ & bc & 21.37ab & $5.20 \mathrm{a}$ & & Da & $0 \mathrm{c}$ \\
\hline \multirow[t]{2}{*}{ Mahogany } & Shade & $5.83 b$ & $5.83 b$ & $0.00 \mathrm{~b}$ & $18.79 d$ & $63.06 \mathrm{e}$ & $56 \mathrm{~d}$ & $19.33 \mathrm{~cd}$ & $2.29 \mathrm{~d}$ & $3.64 c$ & $5.93 \mathrm{c}$ & $38.68 b c$ \\
\hline & Ambient & $5.83 \mathrm{~b}$ & $5.83 \mathrm{~b}$ & $0.00 \mathrm{~b}$ & $21.50 \mathrm{a}$ & $98.25 \mathrm{a}$ & $55.65 b$ & $20.85 b c$ & $4.01 \mathrm{~b}$ & $5.03 \mathrm{bc}$ & $9.04 \mathrm{~b}$ & $43.87 \mathrm{a}$ \\
\hline \multirow[t]{2}{*}{ Sissoo } & Shade & $7.50 \mathrm{a}$ & $7.33 a$ & $0.17 \mathrm{a}$ & $20.05 b c$ & $71.89 \mathrm{c}$ & $48.89 \mathrm{c}$ & $16.58 \mathrm{e}$ & $3.23 \mathrm{c}$ & $5.75 b$ & $8.98 \mathrm{~b}$ & $35.70 \mathrm{c}$ \\
\hline & Ambient & $6.50 \mathrm{~b}$ & $6.33 b$ & $0.17 \mathrm{a}$ & $19.46 \mathrm{~cd}$ & $69.36 \mathrm{~d}$ & $36.47 \mathrm{~d}$ & $23.06 \mathrm{a}$ & $3.22 \mathrm{c}$ & $4.29 b c$ & $7.51 b c$ & 43.10ab \\
\hline CV (\%) & & 8.36 & 11.21 & 12.74 & 3.90 & 4.72 & 8.65 & 7.29 & 7.09 & 22.96 & 13.88 & 10.25 \\
\hline \multicolumn{2}{|c|}{ Level of significance } & * & * & * & $*$ & * & * & $*$ & * & * & * & * \\
\hline
\end{tabular}

Note: In a column, figures having the similar letter(s) or without letter(s) do not differ significantly as per DMRT; *= Significant at $5 \%$ level of probability.

\section{Effective tillers hill ${ }^{-1}$}

The condition of sunshine (shade and ambient condition) had no significant effect on effective tillers hill $^{-1}$ except mango tree (Table 2). The effective tillers hill ${ }^{-1}$ differ significantly in case of rice produced in shade and ambient condition of mango tree. It was found that significantly higher under shade of sissoo tree and under ambient condition of mango tree. There was no significant difference in effective tillers hill $^{-1}$ of rice produced in shade and ambient condition of mahogany tree (Table 2). Similar results found by Sunilkumar and Geethakumari (2002) reported that the highest number of productive tillers hill ${ }^{-1}(6.2)$ and the lowest number of productive tillers hill $^{-1}$ (3.2) of upland rice cultivars at $0 \%$ shading and $40 \%$ shading which was similar to the present findings.

\section{Non-effective tillers hill $^{-1}$}

The results revealed that non-effective tillers hill $^{-1}$ of rice response significantly in shade and ambient condition. The non-effective tillers hill $^{-1}$ of rice produced in shade and ambient condition of mango trees varied significantly. The shade condition of mango trees produced significantly much higher number of non-effective tillers hill $^{-1}$ whereas, in ambient condition there are almost nil number of noneffective tillers hill $^{-1}$. There was no significant difference in number of non-effective tillers hill $^{-1}$ between shade and ambient condition under both mahogany and sissoo trees (Table 2). Islam (2007) reported that the highest noneffective tillers hill ${ }^{-1}(5.66)$ of rice was produced by jhau tree at shade condition in the late morning in his study which was supportive to the results.

\section{Panicle length $(\mathrm{cm})$}

The panicle length of rice was significant at 5\% level of probability due to sunshine condition (shade and ambient condition) (Table 2). The panicle length was found significantly different due to different trees in both shade and ambient condition. The panicle length was significantly reduced by shade area of mahogany (Table 2). The similar type of result found by Singha et al., (2015) that the length of the panicle $(31.80 \mathrm{~cm})$ was increased in shade free condition which is statistically similar to the treatment of south direction i.e. $31.20 \mathrm{~cm}$. The lowest length of the panicle $(19.73 \mathrm{~cm})$ was recorded under treatment $0.0-2.0 \mathrm{~m}$ from the base of tree row of north direction of Akashmoni-rice based agroforestry system.

\section{Filled grains panicle ${ }^{-1}$}

The filled grains panicle ${ }^{-1}$ of rice varied significantly due to shade and ambient condition (Table 2). The higher grains panicle $^{-1}$ of rice was produced in the ambient condition. The ambient condition provided sufficient sunshine intensity for assimilation, transfer assimilates to grain which lead good grain filling. Rice produced in the shade area of mango and mahogany trees possess lower grains panicle ${ }^{-1}$ compared with ambient condition of these trees (Table 2). It was recorded that out of three tree-rice associations, the highest filled grains panicle ${ }^{-1}$ (98.25) under ambient condition of mahogany tree while the lowest filled grains panicle ${ }^{-1}(38.86)$ under shade condition of mango tree (Table 2). Shammi et al., (2016) stated that in regard of effective grain per panicle of rice, it was counted the highest (140.65) and the lowest (129.42) was recorded under Albida and Jhau tree-rice agroforestry system respectively which was similar with present findings.

\section{Unfilled grains panicle ${ }^{-1}$}

The sunshine condition (i.e. shade area and shade free area) had significant effect on unfilled grain panicle ${ }^{-1} /$ sterile spikelet's panicle ${ }^{-1}$. Shade condition produced the highest sterile spikelet's panicle ${ }^{-1}$ compared with shade free area (Table 2). Insufficient sunshine intensity under shade condition could not provide enough sunlight for photosynthesis resulted in sterile grains in the panicle. Sterile spikelet's panicle ${ }^{-1}$ varied significantly due to shading effect of different trees. The highest sterile spikelet's panicle ${ }^{-1}$ (86.11) was recorded in the rice produced in mango shade area and the lowest sterile spikelet's panicle ${ }^{-1}$ (36.47) was recorded in the rice produced in shade free area of sissoo tree (Table 2). Vityakon et al., (1993) observed the shading on growth and yield of paddy rice (R-6) where they found the highest unfilled grain $(9.6 \%)$ at $50 \%$ level of shading and the lowest unfilled grain $(8.4 \%)$ at full sunlight condition which was supportive to present study.

\section{0-grian weight (g)}

1000 -grain weight (g) was observed significant in shade and ambient condition (Table 2). The weight of 1000-grain weight of rice varied significantly due to shading effect of different trees. The lowest 1000-grain weight of rice $(16.58$ g) was found in the rice produced in sissoo shade area and the highest 1000-grain weight of rice (23.06 g) was observed in the rice produced in sissoo ambient area. Thousand grain weight of rice produced in the shade area was lowest in all trees cases compare to ambient area (Table 2). This finding 
was similar to the result found by Islam et al., (2006) where the open field showed highest 1000-grain weight of rice and among the different pruned tree the highest and lowest 1000 grain weight (24.63 $\mathrm{g}$ and $23.49 \mathrm{~g}$ ) was produced under severe and light pruned sissoo tree. The 1000-grains weight of Vietnamese cultivars of rice plant under shading condition decreased about $0.9-8.0 \%$ in 2015 and $0.4-13.5 \%$ in 2016 of that under natural light condition reported by Thuy (2018).

\section{Grain yield (tha $\left.{ }^{-1}\right)$}

The grain yield of rice was significant both for shade and ambient condition. Two times higher grain yield was produced in ambient condition than from shade area (Table 2 ). The grain yield of rice was significantly affected due to different types of trees for account of shading effect. The result showed that numerically the lowest grain yield of rice $\left(1.68\right.$ tha $\left.^{-1}\right)$ was produced in the mango tree shade area and the highest grain yield (5.20 tha $\left.{ }^{-1}\right)$ in Mango tree ambient area. The grain yield of rice was differed significantly from mahogany tree shade area to mahogany ambient area. There was no significant variation on grain yield of rice in the sissoo tree shade and sissoo ambient area (Table 2). The grain yield reduction was the highest under mango trees (32.31\% of the ambient condition), medium reduction under mahogany trees $(57.11 \%$ of ambient condition) whereas, the rice yield of the shade areas under sissoo trees was found as equal to the ambient condition (Table 2). Similar findings of Thuy (2018) where he stated that grain yield of fourteen Vietnamese cultivars of rice plant in shading condition reduced about 32.2-65.0\% in 2015 and $15.5-47.4 \%$ in 2016 of natural light condition. In both of years, the most sensitive cultivars to shading is 'Jasmine 85 ', which grain yield reduced to $65.0 \%$ and $38.5 \%$ of natural light condition in 2015 and 2016, respectively. Nandy et al., (2003) observed $10 \%$ lower paddy yield of rice plant, c.v. Koshihikari in shaded plot with $78 \%$ of full solar radiation than un-shaded plot with $100 \%$ solar radiation at Fukui Prefecture Agriculture Expansion Station in Japan.

\section{Straw yield $\left(\right.$ tha $\left.^{-1}\right)$}

The significant response was observed in case of straw yield $\left(\right.$ tha $\left.^{-1}\right)$ of rice due to shade and ambient condition of different tree species. There was very much significant difference in the straw yield of rice produced in shade and ambient area of mango tree. The results showed that the highest straw yield (7.65 tha $^{-1}$ ) was recorded under mango tree at ambient condition and the lowest straw yield $\left(3.64 \mathrm{tha}^{-1}\right)$ was found under mahogany tree shade area which was similar with straw yield produced in the sissoo tree (Table 2). Roy et al., (2006) stated that the highest straw yield $\left(3.71 \mathrm{tha}^{-1}\right)$ and the lowest straw yield $\left(2.76\right.$ tha $\left.^{-1}\right)$ were found Eucalyptus camaldulensis tree- rice association plot and Albizzia lebbeck tree-rice association in their experiment which was more or less similar to present results. Moula (2009) observed that the yield of green straw of KazolShail and BRRI dhan32 in the unshaded area are $106.75 \%$ and $86.20 \%$ higher than in the shaded area, respectively.

\section{Biological yield $\left(\right.$ tha $\left.^{-1}\right)$}

The results indicated that biological yield $\left(\right.$ tha $\left.^{-1}\right)$ was significant for shade and ambient condition (Table 2). The biological yield of rice was significant due to the shading effect of different tree species. The biological yield of rice varied significantly from shade to ambient area of mango and mahogany trees. The lowest biological yield of rice (5.93 tha $^{-1}$ ) was observed in the mahogany tree shade area and the highest biological yield (13.20 tha $\left.{ }^{-1}\right)$ was found in the mango tree ambient area. There was less significant difference in biological yield $\left(\right.$ tha $\left.^{-1}\right)$ of rice produced in Sissoo tree shade and ambient area (Table 2). Quddus and Pendleton (1991) found that $8 \%$ lower yield of main rice crops in the shaded plots than unshaded plots. In following ratoon rice, they found $72 \%$ higher yield in unshaded plots than shaded plots.

\section{Harvest index (\%)}

The harvest index is an important yield component parameter which can lead sufficient idea to biomass and their economic parts in general cereal crops. The harvest index of rice was found significant for shade and ambient condition (Table 2). The lowest harvest index $(24.94 \%)$ was found in the rice grown in mango tree shade area and the higher harvest index $(43.87 \%)$ was found in rice grown in mahogany tree ambient area (Table 2). Similar type of findings was revealed by Sharif et al., (2010) in their study and they observed that the lowest harvest index (38.910\%) was found in the rice grown in the noon shade area under akashmoni and the highest harvest index $(46.250 \%)$ was found in rice grown in the shade free area of jhau tree which was statistically dissimilar to other treatments which was supportive to the present study.

\section{Conclusion}

From the present study, it was noted that increase in plant height, non-effective tillers hill ${ }^{-1}$, sterile spikelet's panicle ${ }^{-1}$ and decrease grain yield $\left(\right.$ tha $\left.^{-1}\right)$, effective tillers hill ${ }^{-1}$, grains panicle $^{-1}$ were observed under mango trees. The lesser number of effective tillers hill ${ }^{-1}$, grains panicle ${ }^{-1}$, grain yield $\left(\right.$ tha $\left.^{-1}\right)$ and biological yield $\left(\right.$ tha $^{-1}$ ) were observed due to shading effect of mahogany trees. Comparatively higher sunshine intensity existed in the Sissoo tree shade area due to higher amount of penetrating light. Therefore, no significant difference in sunshine intensity between shade and ambient condition of sissoo trees was observed. This leads to the similar yield and yield components of rice between shade and ambient rice field under sissoo tree. From the above findings, it can be concluded that sissoo-boro rice is found suitable than the other mango and mahogany tree rice based agroforestry system considering growth and yield contributing characters of Boro rice.

\section{References}

AIS (Agricultural Information Service) (2016). Krishi Diary 2016. Agricultural Information Service, Khamarbari, Farmgate, Dhaka-1215, Bangladesh.

Alridiwirsah, Harahap EM, Akoeb EN, Hanum H (2018). Growth and production of new superior rice varieties in the shade intensity. IOP Conference Series: Earth and Environmental Science, 122: 1-7. doi :10.1088/17551315/122/1/012024

FRG (Fertilizer Recommendation Guide) (2012). Bangladesh Agricultural Research Council, Farmgate, New Airport Road, Dhaka -1225. pp. 14-123.

Deng F, Wang L, Yao X, Wang JJ, Ren WJ, Yang WY (2009). Effects of different-growing-stage shading on Rice grain-filling and yield, Journal of Sichuan Agricultural University, 03.

FAO (Food and Agricultural Organization) (1988). Land Resources Appraisal of Bangladesh Agricultural Development, Report-2. Agro-ecological Region of Bangladesh. pp. 212-221. 
Fujita K (2010). Re-thinking Economic Development. The Green Revolution, Agrarian Structure and Transformation in Bangladesh. Japan: Kyoto University Press.

Gilmour DA (1995). Rearranging trees in the landscape in the middle hills of Nepal. In: Tree management in farmer strategies: Responses to agricultural intensification (Arnold JEM and Dewees PA, Eds.), Oxford University Press. Oxford, UK. pp. 21-42.

Ginting J, Damanik BSJ, Sitanggang JM, Muluk C (2015). Effect of shade, organic materials and varieties on growth and production of upland Rice. International Journal of Scientific and Technology Research, 4(1): 68-74.

Gujral RS (1990).Homestead and agroforestry systems in Asia. In: Homestead plantation and agroforestry in Bangladesh (Abedin MZ, Lai CK and Ali MO, (eds.), Proceedings of a National Workshop held on 17-19 July 1988 in Bangladesh Agricultural Research Institute, Joydebpur, Gazipur, Bangladesh. pp. 1-7.

Hossain MI (2008). Effect of level of pruning of Jhau (Casuarina equisetifolia) on the yield and yield contributing characters of aman rice. M.S. Thesis, Department of Agroforestry, Bangladesh Agricultural University, Mymensingh, Bangladesh.

Islam MR (2007). Effect of shading time on the yield and yield contributing characters of rice cv. BR11. M.S. Thesis, Department of Agroforestry, Bangladesh Agricultural University, Mymensingh, Bangladesh.

Islam KK, Rafiqul ATM, Hoque, Mamun MF (2006). Effect of level of pruning on the performance of Rice-Sissoo based agroforestry system. American Journal of Plant Physiology, 1: 13-20.

Karim AB, Savill PS (1991). Effect of spacing on growth and biomass yield production of Gliricidia sepium (Jack) Walp in an alley cropping system in Sierra Leone. Agroforestry System, 16: 213-222.

Miah MG, Rahman MA, Haque DMM (1999). Performance of onion under different reduced light levels for agroforestry and intercropping systems. Bulletin of the Institute of Tropical Agriculture, Kyushu University, 22:31-38.

Moula MG. (2009). Effect of shade on yield of rice crops. Pakistan Journal of Agricultural Research, 22(1\&2): 2427.

Nandy P, Paul SP, Moula MG, Imam MF, Basak SR, Mian MAQ, Mannan MA (2003). Stakeholder analysis through participatory rural appraisal for land use and joint forest management in raised coastal areas. PRA Bull. p. 58.

Quddus MA, Pendleton JW (1991). Effects of shading on yield of main rice crop and the following ratoon rice. Bangladesh Rice Journal, 2(1\&2): 79-92.
Ren WJ, Yang WY, Fan GG, Zhu XM, Ma ZH, Xu JW (2003). Effect of low light on dry matter accumulation and yield of Rice, Journal of Sichuan Agricultural University, 04.

Roy KC, Salam MA, Bari MS, Hossain MF (2006). Performance of multipurpose trees and field crops under different management practices in an agroforestry system. Journal of the National Science Foundation of SriLanka, 34(1): 15-19. DOI: http://doi.org/10.4038/jnsfsr.v34i1.2071

Schoch PG (1972). Effects of shading on structural characteristics of the leaf and yield of fruit in Capsicum annum. Journal of the American Society of Horticultural Science, 97(4): 461-464.

Shammi R, Abdullah MR, Rahman MM (2016). Yield of rice in response of shade and orientation. Journal of Bioscience and Agriculture Research, 6(2): 547-552.

Sharif MO, Wadud MA, Mondol MA, Tanni AD, Rahman GMM (2010). Effect of shade of different trees on growth and yield of aman rice. Journal of Agroforestry and Environment, 4(2): 167-172.

Singh L (1988). Adoption and yield of potato under low light intensity. Indian Journal of Plant Physiology, 31(1): 114116.

Singha AK, Rahman MM, Wadud MA, Rahman GMM (2015). Rice cultivation along the north-south orientation of a five years old strip plantation of akashmoni tree. Journal of Agroforestry and Environment, 9(1\&2): 45-48.

Srikrishnah S, Peiris SE, Sutharsan S (2012). Effect of shade levels on leaf area and biomass production of three varieties of Dracaena sanderiana L. in the dry zone of Sri Lanka. Tropical Agricultural Research, 23(2): 142151.

Sutater T (1987). Shading and mulching effect on potato yield. Bull. Penelitian Hortikultura, 15(1): 191-198. [Cited from Field Crop Abstract. 15(5): 775, 1990].

Sunilkumar B, Geethakumari VL (2002). Shade response of upland rice cultivars (Oryza sativa L.) as influenced by silica application. Journal of Tropical Agriculture, (40): 67-70.

Thuy TL (2018). Effect of shading and high temperature on dry-matter production, yield and grain appearance quality of Vietnamese Rice Cultivars (Oryza sativa L.) in Paddy Field. Ph.D. Thesis, Okayama University, 3-1-1 Tsushima-naka, Kita-ku, Okayama 700-8530, Japan.

Torquesiau E (1994). Ecological interactions in Agroforestry. Lecture Note, Introduction training Course. ICRAF. pp. 1-36.

Vityakon P, Sae-Lee S, Seripong S (1993). Effects of tree litter and shading on the growth and yield of paddy rice in Northeast Thailand. Kasetsart Journal (Natural Science), 27: 219-222. 